\title{
Redescription of Tripaphylus musteli (van Beneden, 1851) (Copepoda: Sphyriidae) and the relegation of Paeon Wilson, 1919 to synonymy with Tripaphylus Richiardi in Anonymous, 1878
}

\author{
George W. Benz $\cdot$ Geoffrey A. Boxshall $\mathbb{C}$
}

Received: 13 April 2017/ Accepted: 9 May 2017 / Published online: 1 June 2017

(C) The Author(s) 2017. This article is an open access publication

\begin{abstract}
Tripaphylus musteli (van Beneden, 1851) (Copepoda, Siphonostomatoida, Sphyriidae) is redescribed from an adult female collected from the branchial chamber of a starry smooth-hound, Mustelus asterias Cloquet (Carcharhiniformes, Triakidae), captured in the English Channel off Portland, UK. The new account of $T$. musteli is the first based on a complete adult female and highlighted the lack of a robust distinction separating Tripaphylus Richiardi, in Anonymous, 1878 and Paeon Wilson, 1919 prompting us to relegate Paeon to a junior subjective synonym of Tripaphylus. In the light of this synonymy the eight
\end{abstract}

This article was registered in the Official Register of Zoological Nomenclature (ZooBank) as urn:lsid:zoobank.org:pub:DA909 57B-2472-4F9F-9877-E77FA30EC750. This article was published as an Online First article on the online publication date shown on this page. The article should be cited by using the doi number. This is the Version of Record.

This article is part of the Topical Collection Arthropoda.

George G. Benz: Deceased

G. W. Benz

Evolution and Ecology Group, Biology Department, Middle Tennessee State University, Murfreesboro,

TN 37132, USA

\section{G. A. Boxshall ( $\square)$}

Department of Life Sciences, Natural History Museum,

Cromwell Road, London SW7 5BD, UK

e-mail: G.Boxshall@nhm.ac.uk former species of Paeon are transferred to Tripaphylus as follows: T. ferox (Wilson, 1919) new combination, T. elongatus (Wilson, 1932) new combination, $T$. vassierei (Delamare Deboutteville \& Nuñes-Ruivo, 1954) new combination, T. lobatus (Kirtisinghe, 1964) new combination, T. asymboli (Turner, Kyne \& Bennett, 2003) new combination, T. versicolor (Wilson, 1919) new combination, T. australis (Kabata, 1993) new combination, and T. triakis (Castro Romero, 2001) new combination. Comparisons between terminology used in this report and that in the literature indicate that all transformed adult females of Tripaphylus probably possess a full complement of cephalic appendages and maxillipeds. All limbs, with the exception of the maxillae share a general morphological similarity to the corresponding appendages of conspecific males. The maxilla of the transformed adult female of Tripaphylus is a small digitiform protuberance associated with a swelling in some species.

\section{Introduction}

Adult females of Tripaphylus Richiardi, in Anonymous, 1878 and Paeon Wilson, 1919 (Copepoda, Siphonostomatoida, Sphyriidae) exclusively infect the walls of the buccal and branchial chambers of elasmobranch fishes (Wilson, 1919, 1932). Fully developed adult females are highly transformed relative to their corresponding adult males. They are mesoparasites (sensu Kabata, 1979), living with the 
head and neck region embedded in the host while the trunk and ovisacs trail free in the surrounding water (Wilson, 1919). This lifestyle allows the female to attain large body size, while being firmly attached in a partially protected microhabitat that provides hatching larvae with access to the external environment for dispersal. In addition, the infection site also allows for blood feeding with access to the large blood vessels servicing the gills. In this paper we redescribe Tripaphylus musteli (van Beneden, 1851) from an adult female specimen collected from the branchial chamber of the type host, a starry smooth-hound, Mustelus asterias Cloquet. We also recognise Paeon as a junior subjective synonym of Tripaphylus, and provide comments aimed at standardizing the interpretation of the paired cephalosomic appendages across Tripaphylus species.

\section{Materials and methods}

The starry-hound Mustelus asterias was captured by trawling and examined after spending several weeks alive in a holding tank at the Native Marine Species Centre, Portland, UK. The host was killed and the copepod was excavated from the host and fixed in $70 \%$ ethanol. The specimen was photographed before being cleared in lactic acid. After clearing, the specimen was observed on a Leitz Diaplan microscope using differential interference contrast. Drawings were made using a drawing tube; measurements were made using a stage micrometer. Anatomical terminology conforms mostly to Kabata (1979) and Huys \& Boxshall (1991). Names of hosts follow FishBase (Froese \& Pauly, 2017).

\section{Order Siphonostomatoida Burmeister, 1835 Family Sphyriidae Wilson, 1919}

\section{Tripaphylus musteli (van Beneden, 1851)}

Syns Lerneonema musteli van Beneden, 1851 of van Beneden (1851a, b) and Vogt (1877); Trypaphylum musteli (van Beneden, 1851) of Anonymous (1878), Wilson (1919), van Oorde-de-Lint \& Schuurmans Stekhoven (1936), Kirtisinghe (1964) and Pillai (1985); Tripaphylus musteli (van Beneden, 1851) of Richiardi (1880), Valle (1880), Carus (1885), Brian (1906), Scott \& Scott (1913), Yamaguti (1963), Kabata (1979), Kazachenko (2001), Boxshall \&
Halsey (2004); Lernaeenicus musteli (van Beneden, 1851) of Bassett-Smith (1899) and Scott (1904)

Host and locality of new specimen: Starry smoothhound, Mustelus asterias Cloquet (Carcharhiniformes, Triakidae) captured in English Channel off Portland, UK; host kept alive in holding tank until examined on 17 January 2014.

Material examined: Ovigerous female (no attached male); neck of specimen broken during dissection but both parts recovered and restored digitally in Fig. 1; deposited in the Natural History Museum, London (Registration number NHMUK 2014.23).

Other specimens examined: Two headless ovigerous females (no attached male), from M. mustelus ( $M$. vulgaris on label), Caernarvon Bay, UK, presented by T. Scott and A. Scott (BM(NH) Registration numbers 1913.9.18.324-325).

Site in host: Partially embedded in branchial chamber wall of host beyond distal perimeter of gill filament array.

\section{Description (Figs. 1-3)}

Transformed adult female. Body (Figs. 1, 2A) comprising cephalothorax, neck, and trunk followed by small abdomen bearing pair of posterior processes; neck exhibiting torsion along longitudinal axis. Body dimensions $(\mathrm{mm})$; reported as single measurements from complete specimen followed in some instances by measurements of headless Natural History Museum specimens BM(NH) 1913.918.324 and 1913.9.18.325: total length (cephalothorax tip to abdomen tip excluding posterior processes) 22.3, cephalothorax length 2.4 , cephalothorax width 1.6 , neck length 12.7 , neck width 1.4, trunk length (neck boundary to abdomen base) 7.5 (6.7, 8.4), trunk width 3.2 (3.0, 3.3), abdomen length (not including posterior processes) $0.3(0.3,0.4)$, abdomen width $0.5(0.4,0.5)$, right posterior process length $5.6(4.2,6.6)$, right posterior process width $0.7(0.7,0.8)$, left posterior process length $6.1(5.6,6.5)$, left posterior process width 0.8 $(0.7,0.8)$, right ovisac (incomplete, tip ruptured) length 7.7, right ovisac width 1.2 , left ovisac length 7.2 , left ovisac width 1.3. Body regions of complete specimen expressed as percentage of total length: head length $10.8 \%$, neck length $57.0 \%$, trunk length $30.1 \%$, abdomen length (not including posterior processes) $1.4 \%$, right posterior process length $27.0 \%$, left posterior process length $27.0 \%$. 


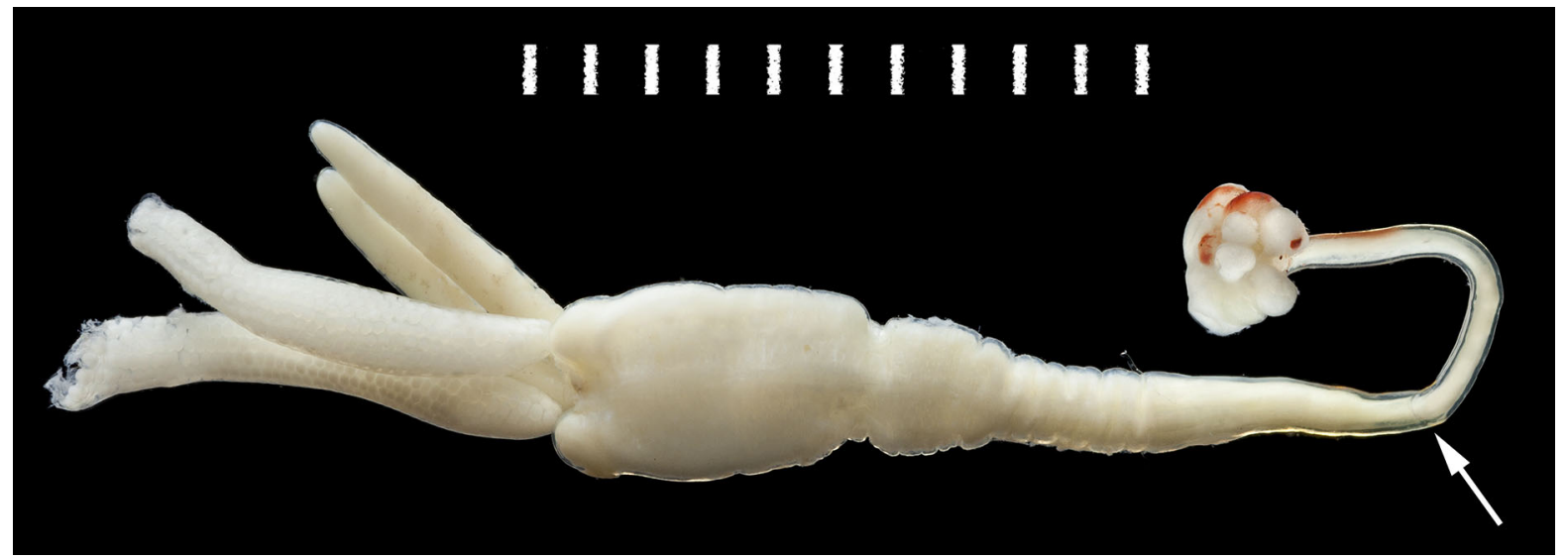

Fig. 1 Tripaphylus musteli (van Beneden, 1851) (Siphonostomatoida, Sphyriiidae) transformed ovigerous female from a starry smooth-hound Mustelus asterias (Carcharhiniformes, Triakidae) captured in the English Channel off Portland, UK. Scale-bar: $1 \mathrm{~cm}$ divided into $\mathrm{mm}$
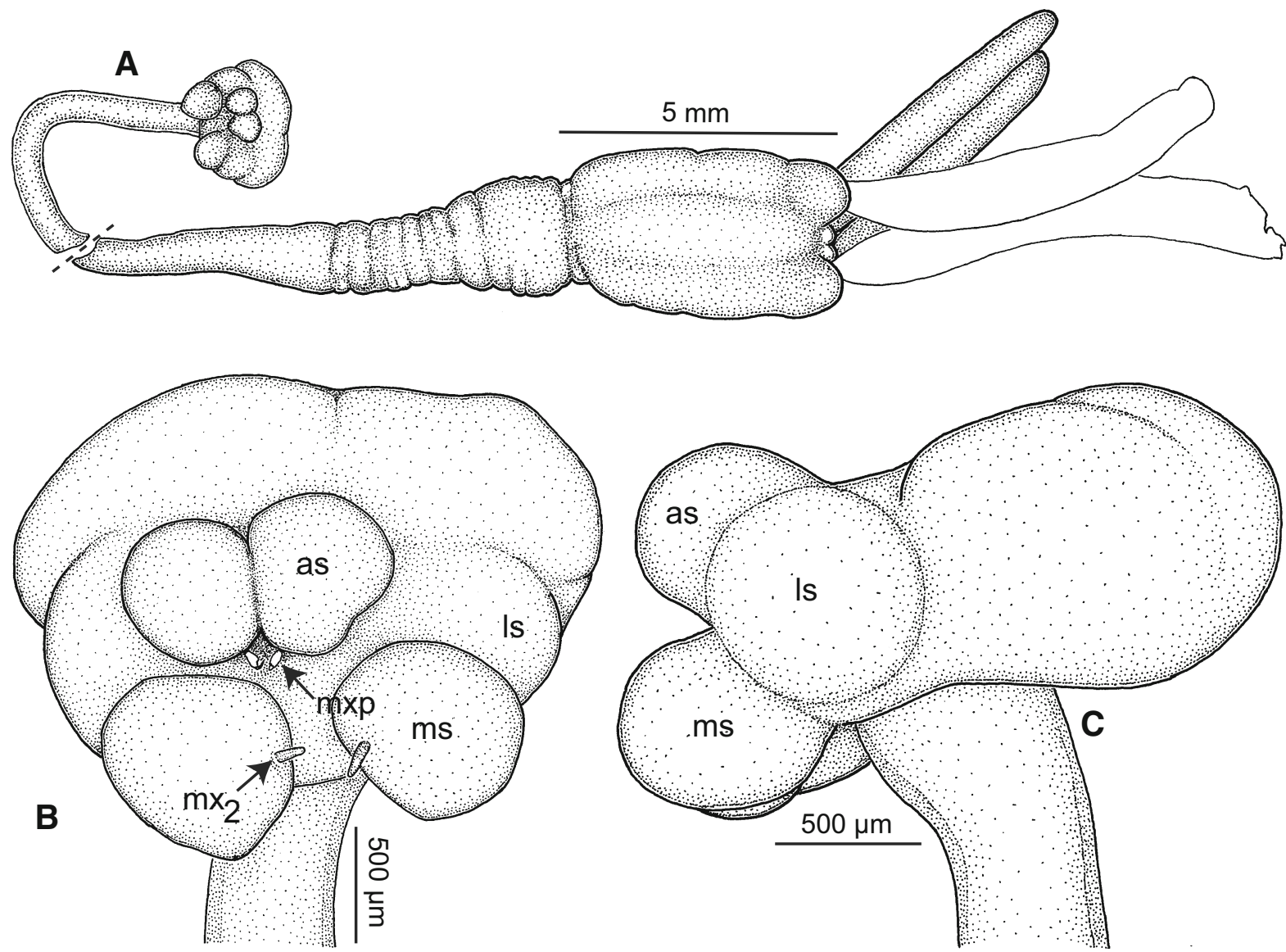

Fig. 2 Tripaphylus musteli (van Beneden, 1851) A, General habitus; decapitated specimen with neck aligned (at dashed line) to approximate intact condition; head in ventral view, trunk in dorsal view; eggs within ovisacs not illustrated; B, Cephalothorax (head), ventral view; C, Left lateral view. Abbreviations: as, antennal swelling; ls, lateral swelling; $m s$, maxillary swelling; $\mathrm{mx}_{2}$, maxilla; $m x p$, maxilliped 

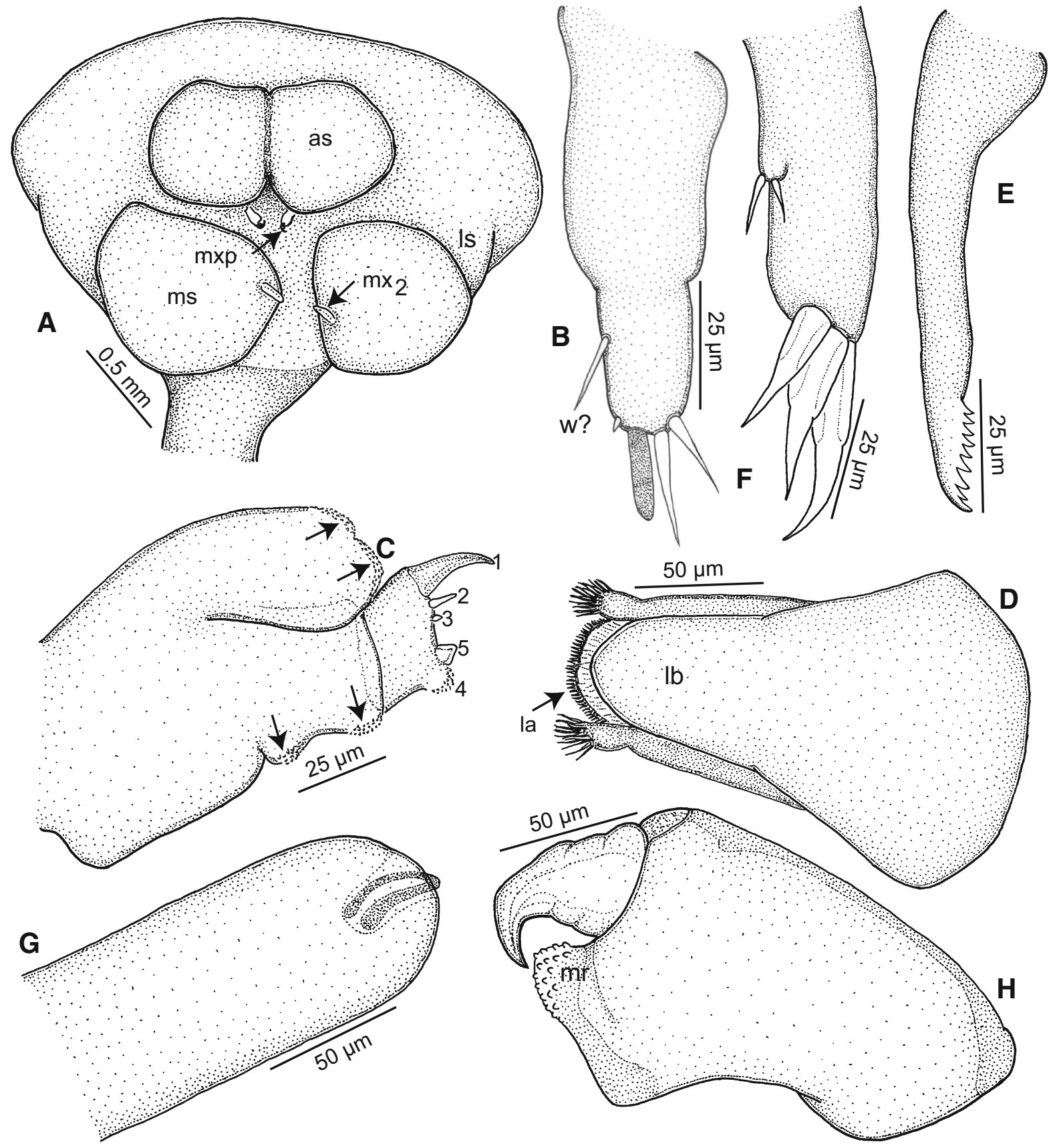

Fig. 3 Tripaphylus musteli (van Beneden, 1851). A, Cephalothorax (head), slightly different ventral view than that depicted in Fig. 1B; B, Antennule; C, Antenna; arrows indicate denticulate patches; numbers correspond to element identification convention of Kabata (1979); D, Mouth tube, anterior view; E, Mandible; F, Maxillule, lateral view; G, Maxilla; H, Maxilliped. Abbreviations: as, antennal swelling; la, labium; lb, labrum; ls, lateral swelling; mr, myxal region of maxilliped; $\mathrm{ms}_{\text {, }}$ maxillary swelling; $\mathrm{mx}_{2}$, maxilla; mxp, maxilliped; w?, whip?

Cephalothorax bulbous in ventral view (Figs. 2AB, 3A), with 2 pairs of well-defined ventral swellings along midline, less-defined pair of lateral swellings, deeper than tall in lateral view (Fig. 2C), wider than tall in dorsal view with slight medial indentation along anterior border (Fig. 2B). First pair of well-defined 
swellings (antennary swellings) meeting at midline, obscuring antennules, antennae, mouth tube containing mandibles and maxillules (Figs. 2B, 3A). Second pair of well-defined, slightly larger swellings (maxillary swellings; Figs. 2B, 3A), positioned posterior to and lateral to antennary swellings, with gap between medial aspects; each swelling bearing small digitiform maxilla distally. Subtle lateral swellings (Figs. 2B, C, $3 \mathrm{~A})$ expressed, flanking antennary and maxillary swellings. Neck (Fig. 2A) cylindrical, anterior portion with smooth border, posterior portion with wrinkled cuticle (possibly due to contraction post-mortem); diameter expanding slightly at junction with head and to greater degree toward confluence with trunk. Trunk (Figs. 1, 2A) about twice as long as wide, slightly compressed dorsoventrally, width constant along most of length, posterior margin with small lateral lobes. Abdomen (Fig. 2A) represented by small tubercle bearing 2 cylindrical and blunt tipped posterior processes ventrally; posterior processes ventral to genital and oviduct openings. Ovisacs (Fig. 1A) cylindrical, longer than posterior processes, egg arrangement multiseriate, eggs spherical.

Coloration of live specimen off white, with red blotches primarily along portions of upper neck and ventral surface of head; recently fixed specimen (NHMUK 2014.23) off white with red blotches; older fixed specimens (BMNH 1913.9.18.324-325) pale brown with blackish blotches on neck, corresponding to red patches illustrated in Scott \& Scott (1913: pl. LI, Figure 1).

Antennule (Fig. 3B) indistinctly 2-segmented with constriction delimiting basal part from narrower distal region; narrow region with long thin naked medial seta (whip?), apical region with small naked seta, aesthetasc and two long naked setae. Antenna (Fig. 3C) biramous, protopodal part unarmed; bulbous exopod one-segmented, shorter than endopod, apex ornamented with patches of denticles; endopod twosegmented, proximal segment with patches of denticles along medial border (arrowed in Fig. 3C), distal segment with robust hook 1 , naked setae 2 and 5, small seta 3, and denticulated inflation 4 [using Kabata's (1979) terminology].

Mouth tube (Fig. 3D) typical of sphyriids (Sphyriidae) and lernaeopodids (Lernaeopodidae), with anterior labrum and semi-circular (in cross-section) labium, latter with fringe of setules around mouth opening and swollen left and right anterolateral regions appearing as small projections tufted with setules in anterior view. Mandible (Fig. 3E) short, blade with nine teeth of about equal length. Maxillule (Fig. 3F) located lateral to mouth tube, bilobate; small outer lobe on lateral margin bearing 2 naked setae; inner lobe with 3 large naked apical setae, each with swollen base. Maxilla (Fig. 3G) small, digitiform, apically located on maxillary swelling (Fig. 3A); bearing blunt apical element nestled in cavity (element possibly retractile). Maxillipeds either side of midline between mouth tube and maxillary swellings (Fig. 3A); subchelate, each with broad corpus bearing denticulate myxal process opposing tip of subchela (Fig. 3H).

Adult male. None available for study; see Scott \& Scott (1913: pp. 160-161, 229-230, pls. XLV (figure 6), XLIX (figures 1-7) for the most complete description (although inadequate by modern standards).

\section{Remarks}

Van Beneden (1851a) established Tripaphylus musteli in Lerneonema Milne Edwards, 1840, as Lerneonema musteli. The essence of this account was republished during the same year in a different journal (van Beneden, 1851b). The species was mentioned again under its original name by Vogt (1877), but Vogt simply reviewed van Beneden's account and re-used van Beneden's original drawing of the male. The taxon was referred to again in an anonymous report (Anonymous, 1878) of the verbal proceedings of the Natural History Society of Toscania. Anonymous (1878) reported on an oral paper given by Richiardi, who referred to three complete specimens embedded in the hyoid region musculature of Mustelus plebejus Bonaparte $(=M$. asterias Cloquet, starry smoothhound) and concluded that Lernaeonema [sic!] musteli van Beneden could not be placed in either Lernaeenicus Le Sueur or Lernaeonema [sic!] and instead belonged in a new genus related to Sphyrion Cuvier, 1830, for which Richiardi proposed the name Trypaphylum. Authorship was clearly attributed to Richiardi within the anonymous publication and thus Richiardi, in Anonymous, 1878 is the authority for Trypaphylum. Richiardi (1880) subsequently referred to the taxon in his systematic catalogue of parasitic crustaceans from aquatic animal hosts in Italy, but therein spelled it Tripaphylus and mentioned it as a new genus. Both 
spellings have subsequently been used for the genus; for example, Trypaphylum by Wilson (1919), van Oorde-de-Lint \& Schuurmans Stekhoven (1936), Kirtisinghe (1964) and Pillai (1985), and Tripaphylus by Carus (1885), Scott \& Scott (1913), Brian (1906), Yamaguti (1963), Kabata (1979), Dojiri \& Deets (1988), Kazachenko (2001), Boxshall \& Halsey (2004), Benz et al. (2006), and Gómez et al. (2010).

In his highly influential monograph, Kabata (1979) endorsed Richiardi's (1880) spelling, Tripaphylus, in part because the earlier version was published anonymously, though validly under provisions of the International Code of Zoological Nomenclature (ICZN). Kabata construed the 1878 usage as a "lapsus calami (under ICZN Article 32(a)(ii))" (Kabata, 1979: p. 322). According to the fourth edition of the ICZN, to apply this ruling (now numbered 32.5.1) there must be in the original publication itself, "without recourse to any external source of information, clear evidence of an inadvertent error, such as a lapsus calami" (ICZN, 1999: p. 39). The evidence presented by Kabata (1979: p. 322) was, "because one other name mentioned in the same paragraph is spelt incorrectly". Here we document greater use of Tripaphylus since 1880, and, in the interest of nomenclatural stability, we propose to follow Kabata (1979) and deem Tripaphylus to be a justified emendation under ICZN Article 33.2.3.1.

Tripaphylus musteli is a rarely collected and poorly known species. Van Beneden (1851a) based his original description on two incomplete females (decapitated with heads lost) and a male found attached to one of the females. Richiardi (in Anonymous, 1878) reported three intact females, but he gave no species description in that publication or in Richiardi (1880). Valle (1880) reported a single female from the branchial chamber of Mustelus equestris Bonaparte (= Mustelus mustelus) but provided no morphological details. Bassett-Smith (1899) mentioned specimens from the "gills" of Mustelus vulgaris (= Mustelus mustelus) in the collections of the British Museum but we have been unable to trace this material. Andrew Scott (1904) reported the species from the Irish Sea but merely noted its host and infection site. The description by Scott \& Scott (1913) incorporated data from van Beneden's (1851a, b) accounts in combination with new observations gained from examination of at least one headless female measuring $28 \mathrm{~mm}$ in length and of a male found attached to a female. It seems likely that Scott \& Scott's female description was based on the two headless specimens they presented to the Natural History Museum, London, however, no male was deposited by those authors. The headless female figured by Kabata (1979: figures 1459-1460) was one of the two specimens in the NHM collections. The present description of a complete specimen provides the first detailed description of the mouthparts and head of T. musteli, the type-species of the genus.

Kirtisinghe (1964) described a second species of Tripaphylus as Trypaphylum hemigalei based on adults of both sexes collected from the "gill arches" of Hemigaleus balfouri Day (= Chaenogaleus macrostoma (Bleeker), the hooktooth shark, Carcharhiniformes, Hemigaleidae) obtained from a Colombo market (Sri Lanka). He established the species based on the observation that the adult female of $T$. hemigalei was about half the length of T. musteli and possessed a head more transversely elliptical rather than round; furthermore, the males of each species differed regarding particular appendage characteristics. Kabata (1979) remarked that a robust decision regarding the validity of $T$. hemigalei as a species must await a detailed description of the head of T. musteli, and in doing so mentioned the conundrum that while the description of T. musteli by Scott \& Scott (1913) was based on headless adult female specimens, those authors described the female in part as possessing a "Head rounded and furnished with cartilaginous horns" (Scott \& Scott 1913: p. 160) and that description was adopted as part of their generic diagnosis for Trypaphylus (loc. cit.: p. 159). Kabata (1979) noted that while he was unaware of the origin of those details, they had been repeated by several subsequent authors, most notably Wilson (1919) and Yamaguti (1963). In fact, Kirtisinghe (1964) seemed to be aware of those details, as he referred to the head of T. musteli as being round. Furthermore, in addition to other general body features, the presence of an unbranched projection on each side of the head of the adult female of $T$. hemigalei likely was a key factor influencing Kirtisinghe's designation of the generic affiliation for his new species. We too are unaware of the evidence underpinning Scott \& Scott's (1913) description of the head of T. musteli. Nevertheless, based on new details provided here, their remarks seem generally correct, in that at a certain magnification, the head of the adult female of $T$. musteli could be depicted as being rounded (Figs. 1, 2A) and in closer view the tiny 
digitiform maxillae carried on the maxillary swellings (the appendages least likely to be overlooked; Fig. 1B) could be interpreted as being horn-like. Unfortunately, the level of detail provided by Kirtisinghe (1964) regarding the appendages of $T$. hemigalei prevents meaningful comparisons with the details presented herein for $T$. musteli. Even so, we are confident that $T$. hemigalei is distinct from $T$. musteli based on differences in the general shape of the head; specifically, that of the adult female of $T$. hemigalei was noted by Kirtisinghe (1964) to be separated into a median and flanking lateral lobes with laterally projecting horns (maxillae) while our description reveals the head of the adult female of $T$. musteli as possessing welldefined pairs of antennary and maxillary swellings not observed on T. hemigalei.

\section{Discussion}

In the phylogenetic analysis of the Sphyriidae by Benz et al. (2006), Tripaphylus formed an unresolved trichotomy with Paeon group A and a large lineage comprising Norkus Dojiri \& Deets, 1988, Paeon group B, Driocephalus Raibaut, 1999, Lophoura Köllicker in Gegenbauer, Köllicker \& Müller, 1853, Sphyrion Cuvier, 1830, Periplexis Wilson, 1919 and Paeonocanthus Kabata, 1965. In that analysis, group A species of Paeon (comprising the type-species $P$. ferox Wilson, 1919, plus P. elongatus, P. vassierei Delamare Deboutteville \& Nuñes-Ruivo, 1954, P. lobatus Kirtisinghe, 1964 and P. asymboli Turner et al., 2003), and group B species of Paeon (comprised of $P$. versicolor Wilson, 1919, P. australis Kabata, 1993 and P. triakis Castro Romero, 2001), were distinguished from one another based on the form of the trunk and its boundary with the neck, defined as a single character. In Paeon group A species the trunk was noted as being "appreciably longer than wide" and "merges gradually with neck", whereas in Paeon group B species the trunk was depicted as being "broad, roughly orbicular or rhomboid in dorsal view, well delimited from neck" (Benz et al., 2006: p. 3). In the most recent phylogenetic analysis of the family (Gómez et al., 2010), Paeon was treated as a single unit (not divided into group A and group B species), and Tripaphylus and Paeon were recovered as sister taxa. With regard to these two genera, the data matrix of Gómez et al. (2010: Table 2) was identical to that of
Dojiri \& Deets (1988: Appendix II). They were separated only by two characters relating to morphology of the cephalothorax, and the coding for Trypaphylus was presumably based on T. hemigalei using data extracted from Kirtisinghe (1964), given that the cephalothorax of the type-species T. musteli had not hitherto been documented.

All phylogenetic analyses of the sphyriids have been severely handicapped by the lack of detailed data on the structure of the cephalothoracic appendages of particular genera and molecular sequence data. Benz et al. (2006) commented that given the highly transformed morphology and seemingly reduced complexity of female sphyriids, it is likely that a robust phylogenetic hypothesis for the family will only be realized through molecular study.

Description herein of the mouthparts of the transformed females of $T$. musteli confirms their basic structural similarity to that of their corresponding males, as described in Scott \& Scott (1913). Furthermore, we find no characters based on the mouthparts or any other feature that serve to discriminate at the genus level, between species of Tripaphylus and species of Paeon. The type-species of both genera share the same female body form, with a small head and long neck merging gradually into a trunk that bears a small abdomen carrying a pair of posteriorly projecting cylindrical processes originating ventrally. The head carries paired antennary and maxillary swellings in $T$. musteli and similar paired lobes are present in $P$. ferox Wilson, 1919, the type-species of Paeon (see Wilson, 1919: pl. 56, figure 55).

Given the absence of any character that can serve to discriminate between the type-species of Tripaphylus and Paeon, we conclude there is no justification in maintaining the validity of both genera. Tripaphylus has priority and we therefore propose that Paeon be recognized as its junior subjective synonym and that all Paeon species be transferred accordingly. The ten valid species of Tripaphylus resulting from this nomenclatorial change are: T. musteli (type-species) and T. hemigalei, plus T. ferox (Wilson, 1919) new combination, T. elongatus (Wilson, 1932) new combination, T. vassierei (Delamare Deboutteville \& Nuñes-Ruivo, 1954) new combination, T. lobatus (Kirtisinghe, 1964) new combination, T. asymboli (Turner, Kyne \& Bennett, 2003) new combination, $T$. versicolor (Wilson, 1919) new combination, $T$. 
australis (Kabata, 1993) new combination, and $T$. triakis (Castro Romero, 2001) new combination. The monophyletic status of Tripaphylus, as now constituted, needs to be tested to ascertain the status of the group B species of Benz et al. (2006).

Our understanding of Tripaphylus species has always been hampered by a lack of study specimens, damaged study specimens, and inadequate descriptive works that lack sufficient detail, especially regarding the appendages and other head features. Furthermore, the male has been reported for only four of the eight former members of Paeon (T. elongatus n. comb., $T$. ferox n. comb., $T$. vaissierei $\mathrm{n}$. comb., and $T$. versicolor $\mathrm{n}$. comb.) and the only detailed description available is that provided by Lewis (1966) for the male of $T$. vaissierei n. comb. Informed by that, as well as by details of the males of the first two members of Tripaphylus, see Scott \& Scott (1913) and Kirtisinghe (1964), we know that males of Tripaphylus exhibit a general habitus similar in many respects to those of other sphyriids (see Dojiri \& Deets, 1988; Moran \& Piasecki, 1994) and especially lernaeopodids with a type-A male (sensu Kabata, 1979). However, the taxonomic significance of the appendages and other small cuticular structures of the Tripaphylus male is impossible to assess based on our current understanding. For example, while we noted minor antennule, antenna, and maxillule armature differences and maxilliped myxal region differences between males of T. musteli, T. hemigalei and T. vaissierei n. comb., based on the reports of, respectively, Scott \& Scott (1913), Kirtisinghe (1964) and Lewis (1966), some of these differences could be the result of intraspecific variation or observation shortcomings only recognizable through further study and the examination of additional specimens.

Regarding the transformed adult female of Tripaphylus species (as now constituted), the literature includes only five original reports (Wilson, 1919, 1932; Kirtisinghe, 1964; Lewis, 1966; this report) that provide explicit details of at least some of the appendages; even so, the absence of detail lessens the comparative value of Wilson's and Kirtisinghe's contributions. Nevertheless, data suggest that the transformed adult females of all Tripaphylus species possess a full or near full complement of cephalosomic appendages, with all but the maxillae (see below) sharing general similarities with the corresponding appendages of conspecific males as well as with the corresponding appendages of post-metamorphosis adult female lernaeopodids; e.g. compare appendages reported herein and by Lewis (1966) with those of the many lernaeopodids reported by Kabata (1979). Here we re-interpret (Table 1) some of the morphological

Table 1 Comparison of terminology used for the appendages of Tripaphylus species in this and other published accounts (determined by examination of figured appendages and/or text descriptions)

\begin{tabular}{|c|c|c|c|c|c|c|c|}
\hline \multirow[t]{2}{*}{ Species } & \multicolumn{6}{|c|}{ Appendage terminology used in present account } & \multirow[t]{2}{*}{ Reference } \\
\hline & Antennule & Antenna & Mandible & Maxillule & Maxilla & Maxilliped & \\
\hline T. ferox & $\mathrm{nr}$ & Maxilla & $\mathrm{nr}$ & $\mathrm{nr}$ & $\begin{array}{l}\text { Slender finger-like protuberance } \\
\text { (text), migrated second antenna } \\
\text { (figure legend) }\end{array}$ & $\begin{array}{l}\text { Second } \\
\text { maxilla }\end{array}$ & $\begin{array}{l}\text { Wilson } \\
\text { (1919) }\end{array}$ \\
\hline T. versicolor & $\mathrm{nr}$ & $\mathrm{nr}$ & $\mathrm{nr}$ & $\begin{array}{l}\text { Maxilla (text), } \\
\text { first maxilla } \\
\text { (figure legend) }\end{array}$ & $\begin{array}{l}\text { Slender finger-like protuberance } \\
\text { (text), migrated second antenna } \\
\text { (figure legend) }\end{array}$ & $\begin{array}{l}\text { Second } \\
\text { maxilla }\end{array}$ & $\begin{array}{l}\text { Wilson } \\
\quad(1919)\end{array}$ \\
\hline T. elongatus & $\mathrm{nr}$ & $\begin{array}{l}\text { Second } \\
\text { antenna }\end{array}$ & $\mathrm{nr}$ & First mouth-part & $\mathrm{nr}$ & $\begin{array}{l}\text { Second } \\
\text { mouth } \\
\text { part }\end{array}$ & $\begin{array}{l}\text { Wilson } \\
(1932)\end{array}$ \\
\hline T. vaissierei ${ }^{\mathrm{a}}$ & $\mathrm{nr}$ & $\mathrm{nr}$ & Mandible & Maxillule (?) & Maxilliped ? & Maxilla & $\begin{array}{l}\text { Lewis } \\
\quad(1966)\end{array}$ \\
\hline T. asymboli & $\mathrm{nr}$ & $\mathrm{nr}$ & $\mathrm{nr}$ & $\mathrm{nr}$ & Tentacular projection & $\mathrm{nr}$ & $\begin{array}{l}\text { Turner } \\
\text { et al. } \\
\text { (2003) }\end{array}$ \\
\hline
\end{tabular}

\footnotetext{
${ }^{a}$ Lewis (1966) tentatively reported his Tripaphylus (as Paeon) specimens as P. vaissierei, but Kabata (1993) considered them to be conspecific with P. lobatus. We consider Lewis (1966) to have been correct in his determination
}

Abbreviations: $n r$, not reported; ? indicates reported uncertainty in original account 
inferences in Scott \& Scott (1913), Wilson (1919, 1932), Kirtisinghe (1964), Lewis (1966), and Turner et al. (2003).

The swollen head processes of some Tripaphylus species obscure the antennules, antennae, mouth tube, maxillules and maxillae, and the confusion regarding the appendages of Tripaphylus post-metamorphosis females seems linked to the fact that, until this report, the maxillae have not been recognized as such, and have instead been reported as small digitiform protuberances or horns (Table 1). Dojiri \& Deets (1988) proposed a similar structure (an indistinctly segmented digitiform protuberance bearing a subapical pore suspected of being a maxillary gland pore and an apical spine emanating from within a hollow) as the maxilla of Norkus cladocephalus Dojiri \& Deets, 1988 (Sphyriidae) although that structure was not closely associated with a head swelling. The report of Moran \& Piasecki (1994) is also relevant as it depicts the maxillae of Sphyrion lumpi (Krøyer, 1845) as fused swellings, each bearing an apical duct opening and small adjacent projection. Following our interpretation, the maxillae of the adult female of Tripaphylus migrate laterally from near the midline during metamorphosis, sometimes (e.g. T. musteli, T. versicolor $\mathrm{n}$. comb. and $T$. vaissierei $\mathrm{n}$. comb.) they are positioned posterolateral to the maxillipeds. That interpretation is founded in part on the assumption that young females of Tripaphylus likely share a similar general habitus with conspecific adult males, as has been shown for lernaeopodids (Kabata \& Cousens 1973; Piasecki \& Kuźmińska, 2007). Based on these findings, we hypothesise that transformed adult females of Tripaphylus species all possess a full complement of cephalic appendages and we consider it likely that some to many of those appendages remain to be discovered in congeners other than T. musteli and T. hemigalei.

Finally, in light of our better understanding of the morphology of Tripaphylus species and the decision to relegate Paeon to a junior subjective synonym of Tripaphylus, we offer an amended diagnosis for Tripaphylus as follows:

\section{Genus Tripaphylus Richiardi in Anonymous, 1878}

\section{Diagnosis}

Transformed (post-metamorphosis) adult female comprising bulbous head, paired (left and right) swellings on ventral surface of head, long and slender cylindrical neck, wider and somewhat dorsoventrally compressed trunk, with small abdominal tubercle bearing ventrally two long, simple, posteriorly projecting, cylindrical processes; neck sometimes exhibiting torsion. Ovisacs positioned dorsal to posterior processes, straight, multiseriate, containing spherical eggs. Antennules, antennae, mandibles within mouth tube, maxillules and maxillipeds typical of most sphyriids and lernaeopodids. Maxillae small, digitiform, located posterior to maxillipeds. Transformed adult female mesoparasitic, with head and much of neck embedded in host and remainder of body trailing free. Adult male typically found attached to abdominal region of transformed adult female. Adult male general habitus comprising cephalothorax and thoraco-genito-abdominal trunk. Cephalothorax about half body length and wider than trunk, caudal rami at apex of trunk. Antennules, antennae, mandibles, maxillules as in corresponding adult female. Maxillae subchelate, arising from common base. Maxillipeds chelate, arising from large common base such that tips often lie below tip of abdomen. Medial process projecting from ventral surface just anterior to maxillipeds.

Acknowledgements We thank G. Galloway (Native Marine Species Centre, Portland, UK) and K. MacKenzie (University of Aberdeen, Scotland) for (respectively) capturing and notifying one of us $(\mathrm{GAB})$ of an infected smooth-hound. Harry Taylor (NHM, London) took the photograph of the new adult female (Fig. 1).

Funding Completion of this study was facilitated by a noninstructional assignment grant to G. Benz from Middle Tennessee State University.

\section{Compliance with ethical standards}

Conflict of interest The authors declare that they have no conflict of interest.

Ethical approval All applicable institutional, national and international guidelines for the care and use of animals were followed.

Open Access This article is distributed under the terms of the Creative Commons Attribution 4.0 International License (http:// creativecommons.org/licenses/by/4.0/), which permits unrestricted use, distribution, and reproduction in any medium, provided you give appropriate credit to the original author(s) and the source, provide a link to the Creative Commons license, and indicate if changes were made. 


\section{References}

Anonymous. (1878). Adunanza del di 5 maggio 1878. Società Toscana di Scienze Naturali. Processi Verbali, pp. XVIIXXIII.

Bassett-Smith, P. W. (1899). A systematic description of parasitic Copepoda found on fishes, with an enumeration of the known species. Proceedings of the Zoological Society of London, 1899, 438-507, 26 pls.

Benz, G. W., Nagasawa, K., Yamaguchi, A., McMeans, B. C., \& McElwain, A. (2006). New host and ocean records for Driocephalus cerebrinoxius (Sphyriidae, Siphonostomatoida) and a reconsideration of phylogeny within Sphyriidae. Acta Ichthyologica et Piscatoria, 36, 1-9.

Boxshall, G. A., \& Halsey, S. H. (2004). An Introduction to Copepod Diversity. London: The Ray Society, 966 pp.

Brian, A. (1906). Copepodi Parassiti dei Pesci d'Italia. Genova, 187 pp., 21 pls.

Carus, J. V. (1885). Prodromus Faunae Mediterraneae. Vol. I. Coelenterata, Echinodermata, Vermes, Arthropoda. Stuttgart: E. Schweizerbart, 524 pp.

Dojiri, M., \& Deets, G. B. (1988). Norkus cladocephalus, new genus, new species (Siphonostomatoida: Sphyriidae), a copepod parasitic on an elasmobranch from southern California waters, with a phylogenetic analysis of the Sphyriidae. Journal of Crustacean Biology, 8, 679-687.

Froese, R., \& Pauly, D. (Eds) (2017). FishBase. World Wide Web electronic publication, www.fishbase.org.

Gómez, S., Deets, G. B., Kalman, J. E., \& Morales-Serna, F. N. (2010). Lophoura brevicollum n. sp. (Copepoda: Siphonostomatoida: Sphyriidae), a parasite of the smooth grenadier Nezumia liolepis (Gilbert, 1890) (Pisces: Macrouridae) from the Eastern Pacific, and a new record and new host of Lophoura unilobulata Castro R. and Gonzalez. Journal of Crustacean Biology, 30, 129-140.

Huys, R., \& Boxshall, G. A. (1991). Copepod Evolution. London: The Ray Society, $468 \mathrm{pp}$.

ICZN. (1999). International Code of Zoological Nomenclature (4th edition). London: International Trust for Zoological Nomenclature, $306 \mathrm{pp}$.

Kabata, Z. (1979). Parasitic Copepoda of British Fishes. London: The Ray Society, 468 pp.

Kabata, Z., \& Cousens, B. (1973). Life cycle of Salmincola californiensis (Dana 1852) (Copepoda: Lernaeopodidae). Journal of the Fisheries Research Board of Canada, 30, 881-903.

Kazachenko, V. N. (2001). Opredelitel semeǔstv $i$ rodov paraziticheskikh kopepod (Crustacea: Copepoda) ryb. [Key to families and genera of parasitic copepods (Crustacea: Copepoda) of fishes.] Part I (text): 160 pp., Part II (figures): 252 pp. Daĺnevostochny̌̌ Gosudarstvenny̌̌ Tekhnicheskiǐ Rybokhoziaǔstvennyǐ Universitet, Vladivostok (In Russian)

Kirtisinghe, P. (1964). A review of the parasitic copepods of fish recorded from Ceylon with descriptions of additional forms. Bulletin of the Fisheries Research Station, Ceylon, 17, 45-132.
Lewis, A. G. (1966). Copepod crustaceans parasitic on elasmobranch fishes of the Hawaiian Islands. Proceedings of the United States National Museum, 118, 57-154.

Moran, J. D., \& Piasecki, W. (1994). External morphology of the male and female of Sphyrion lumpi (Krøyer, 1845) (Copepoda; Siphonostomatoida; Sphyriidae). Hydrobiologia, 292(293), 171-178.

Piasecki, W., \& Kuźmińska, E. (2007). Developmental stages of Achtheres percarum (Crustacea: Copepoda), parasitic on European perch, Perca fluviatilis (Actinopterygii: Perciformes). Acta Ichthyologica et Piscatoria, 37, 117-128.

Pillai, N. K. (1985). Fauna of India: Parasitic Copepods of Marine Fishes. Zoological Survey of India, Calcutta, 900 pp.

Richiardi, S. (1880). Contribuzioni alla Fauna d'Italia. A. Catalogo sistematico dei Crostacei che vivono sul corpo degli animali. In: Catalogo generale della sezione Italiana all Esposizione internzionale della Pesca in Berlino, pp. 147-152.

Scott, A. (1904). Some parasites found on fishes in the Irish Sea. Proceedings and Transactions of the Liverpool Biological Society, 18, 113-125.

Scott, T., \& Scott, A. (1913). The British Parasitic Copepoda. Vol. I and II. London: The Ray Society, 257 pp., 72 pls.

Turner, T. B., Kyne, P. M., \& Bennett, M. B. (2003). Description of Paeon asymboli n. sp. (Copepoda: Sphyriidae), parasitic on Asymbolus spp. (catsharks) and a new host record for $P$. australis Kabata, 1993. Systematic Parasitology, 56, 235-239.

Valle, A. (1880). Crostacei Parassiti dei Pesci del Mare Adriatico. Bolletino della Società Adriatica di Scienze Naturali in Trieste, 6, 55-90.

van Beneden, G.-J. (1851a). Note sur un Crustacé parasite nouveaux, avec l'énumération des espèces de cette classe qu'on observe sur les poissons du littoral de Belgique. Bulletin de l'Académie Royale des Sciences, des Lettres et des Beaux-Arts de Belgique, 18, 286-290, 1 pl.

van Beneden G.-J. (1851b). Recherches sur quelques Crustacés inférieurs. Annales des Sciences Naturelles, 16, 71-131, pls. 2-6.

van Oorde-de-Lint, G. M.. \& Schuurmans Stekhoven, J. H. (1936). Copepoda X. C 2 . Copepoda parasitica. In: Grimpe, G. \& Wagler, E. (Eds), Die Tierwelt der Nord- und Ostsee, pp. 73-198.

Vogt, C. (1877). Recherches cotières. Second Mémoire. Sur quelques Copépodes parasites a males pygmées habitant les poissons. Mémoires de l'Institut National Génevois, 13, 45-104, pls. III-VI.

Wilson, C. B. (1919). North American parasitic copepods belonging to the new family Sphyriidae. Proceedings of the United States National Museum, 55, 549-604, pls. 50-59.

Wilson, C. B. (1932). The copepods of the Woods Hole region Massachusetts. Bulletin of the United States National Museum, 158, 1-635, 41 pls.

Yamaguti, S. (1963). Parasitic Copepoda and Branchiura of Fishes. New York: Interscience Publishers, 1104 pp. 